\title{
NOVEL APPROACH FOR DISCRIMINATION OF EOSINOPHILIC GRANULOCYTES AND EVALUATION OF THEIR SURFACE RECEPTORS IN A MULTICOLOR FLUORESCENT HISTOLOGICAL ASSESSMENT
}

\author{
G. BILA ${ }^{1}$, M. SCHNEIDER ${ }^{1}$, S. PESHKOVA 1 , B. KRAJNIK ${ }^{2}$, \\ L. BESH ${ }^{3}$, A. LUTSYK ${ }^{1}$, O. MATSYURA ${ }^{3 凶}$, R. BILYY $Y^{\square}$ \\ ${ }^{1}$ Department of Histology, Cytology and Embryology, \\ Danylo Halytsky Lviv National Medical University, Ukraine; \\ ${ }^{2}$ Faculty of Fundamental Problems of Technology, \\ Wroclaw University of Science and Technology, Poland; \\ ${ }^{3}$ Department of Pediatrics 2, Danylo Halytsky Lviv National \\ Medical University, Ukraine; \\ e-mail: r.bilyy@gmail.com; omatsyura@gmail.com
}

Received: 09 January 2020; Accepted: 27 March 2020

Eosinophilic granulocytes mediate immune responses against multicellular parasites and are also the main contributor to such pathological conditions as allergy and asthma. Eosinophils are discriminated with eosin staining in conventional histology using light microscopy. However, molecular detection of antigens and the widely introduced automated analyzers usually require fluorescent markers to allow quantitative determination. Surprisingly, there is no selective CD marker to differentiate eosinophils and basophils. Recently reported analogs to replace hematoxylin and eosin staining for immune-histochemical applications such as DRAQ5 \& eosin are also unsuitable due to wide fluorescent spectra. Different combinations of fluorescent dyes were tested using fluorescent microscopy aimed to develop a simple and specific method for detecting eosinophilic granules, DNA and surface receptors, the approach was used for evaluation of IgE levels (total and specific to casein) on cells of patients suffering from cow milk allergy. We were able to achieve selective visualization of eosinophil granules using aniline blue dye by modifying the method of Berretty \& Cormane (1978) and detecting emission at 440nm; this allowed simultaneous staining of blood smears with anti-IgEFITC (emission at $520 \mathrm{~nm}$ ) and casein-FITC, detection of DNA with propidium iodide (em. $590 \mathrm{~nm}$ ), and also provided specific metachromatic signal of eosinophils in the NIR region (em. $700 \mathrm{~nm}$ ) with subsequent quantification of fluorescent signal. Application of this approach to clinical cases revealed increased IgE levels and increased casein-binding targets on eosinophils in 3 patients with cow milk allergy compared to 2 healthy donors, demonstrating the general usefulness of the approach.

Ke y w ord s: eosinophilic granulocytes, allergy, IgE, histology, detection, clinical case, milk.

\section{Introduction}

Eosinophils are terminally differentiated granulocytes that normally circulate in the blood in low numbers and tend to localize in tissues with mucosal epithelial surfaces. These granulocytes contain many mediators with toxic, immunomodulatory and other actions, can interact with other cell types including lymphocytes and have roles in varied host immune and inflammatory responses [1]. Recent advances in blood granulocyte research related to discovery of neutrophil extracellular traps immediately raised many discussions about the existence of an eosinophil extracellular trap, as another mechanism of their actions [2, 3]. This mechanism can be of great importance considering functions of eosinophils and their role in allergies, tissue damage, and experimental inflammatory models (such as air pouch model [4] or even gallstone formation [5]).

(C) 2020 Bila G. et al. This is an open-access article distributed under the terms of the Creative Commons Attribution License, which permits unrestricted use, distribution, and reproduction in any medium, provided the original author and source are credited. 
Surprisingly, there is no selective CD (cluster of differentiation) marker to stain only eosinophils and not basophils, for example, CD125 [6]. Recently reported analogs to replace $\mathrm{H} \& \mathrm{E}$ for immune-histochemical applications such as DRAQ5 \& eosin (D\&E) [7], [and personal communication with Jonathon Brown] turned out to be unsuitable due to wide fluorescent emission of eosin. Here our aim was to develop a simple and specific method to detect eosinophilic granules using fluorescent microscopy simultaneously with at least 2 other conventional fluorescent dyes and to use this approach for evaluation of IgE levels (total and specific to casein) on cells of patients suffering from cow milk allergy.

\section{Methods}

Patients. Three patients with cow milk allergy were included in the study. They were diagnosed with "atopic dermatitis" according to "Consensusbased European guidelines for the treatment of atopic eczema (atopic dermatitis) in adults and children" [8]. Their main clinical symptoms are summarized in Table 1. Blood of 2 age-matched healthy children that was obtained during routine clinical examination for allergy and defined as "healthy" regarding allergic conditions, served as a control (normal healthy donors [NHDs]).

Fluorescent staining. Aniline blue (AB), eosin, methylene blue, fluorescein isothiocyanate (FITC) and casein were purchased from Sigma (Munich, Germany). AB staining was done with a $0.001 \%$ solution for $60 \mathrm{~s}$, as previously described [9]. Cell DNA was counterstained with $0.1 \mu \mathrm{g} / \mathrm{ml}$ propidium iodide (PI) solution or $0.1 \mu \mathrm{g} / \mathrm{ml}$ DAPI (4',6-diamidino-2phenylindole, Sigma, Munich, Germany) solution or Sytox Green solution (manufacture provided concentration, ThermoFisher Scientific, Germany). Omalizumab (trademark Xolair, Genentech, USA), a recombinant DNA-derived humanized IgG1k monoclonal antibody against human IgE was used to detect the amount of IgE molecules on eosinophils [10]. Labeling of omalizumab with FITC (green), AMCA (blue, 7-amino-4-methyl-3-coumarinylacetic acid) or Cy5,5 (a near-infrared [NIR] cyanine dye) was performed as previously described $[10,11]$ or according to recommendations of the manufacturer. FITC- labeled casein was used to detect the amount of casein-binding targets in patients with milk allergy.

Tricolor fluorescent histology to detect receptors on IgG. Air-dried blood smears were fixed with a few drops of cold methanol, then submerged in $0,001 \% \mathrm{AB}$ solution to stain eosinophil granules for $60 \mathrm{~s}$, washed twice with water, and incubated with antibodies towards IgE or casein (both FITC-labeled) at a dilution of 1:200 in PBS, for $3 \mathrm{~h}$ at $25^{\circ} \mathrm{C}$. Samples were washed 3 times in PBS and counterstained with $0.1 \mu \mathrm{g} / \mathrm{ml}$ PI, for $60 \mathrm{~s}$, then washed with water and either immediately imaged or covered with antifade mounting medium. We achieved reproducible signal upon storing samples for up to 3 weeks at $4{ }^{\circ} \mathrm{C}$ in an environment protected from light.

Fluorescent microscopy. Fluorescent microscopy was performed with an Olympus BX51 fluorescent microscope (Olympus, Tokio, Japan) equipped with OmegaFilters XF407 filter set (OmegaFilters, Brattleboro, USA) and Olympus DP30BW camera (Olympus, Japan) for NIR imaging. Both 40x $0.75 \mathrm{NA}$ and $90 \mathrm{x} 1.0 \mathrm{NA}$ water immersion objectives were used for imaging. Native Olympus software was used for image processing. ImageJ (National Institutes of Health, Bethesda, MD, USA) software was used for image analysis and quantifications. All image analysis was performed under a fixed setting of parameters including exposure and compensation.

FITC-labeling of omalizumab and casein was done as previously described [10] using 5(6)-FITC mixed isomer as the label. Conjugates were tested for efficiency of binding by measuring the F488/ P280 ratio using a Jasco spectrometer (Jasco, Tokio, Japan), purified by Amicon filter centrifugation [12] and stored in $50 \%$ glycerol at $-20{ }^{\circ} \mathrm{C}$.

Statistical analysis. For comparisons of fluorescent signals of cells in the studied groups, the Mann-Whitney U-test for numerical variables was employed. For comparisons of multiple groups vs NHD or the untreated group, Dunn's multiple comparisons test was used. Co-localization analysis was done with Image (NIH) software, with at least 20 high-resolution cell images analyzed, and Pearson's correlation coefficient $(r)$ was calculated using the embedded algorithm. All analyses were performed using Excel 2016 (Microsoft, Redmond, USA) and

Abbreviations: AMCA - 7-amino-4-methyl-3-coumarinylacetic acid, AB - aniline blue, FITC - fluorescein isothiocyanate, H\&E - hematoxylin and eosin, IgE - immunoglobulin E, NHD - normal healthy donor, NIR - near-infrared, $\mathrm{PI}$ - propidium iodide, $\mathrm{RBC}$ - red blood cells. 
Ta b le 1. Characteristics of patients with cow milk allergy

\begin{tabular}{|c|c|c|c|}
\hline Patient's data & Patient 1 & Patient 2 & Patient 3 \\
\hline Age, months & 25 & 39 & 22 \\
\hline Sex & Male & Male & Female \\
\hline Current diagnosis & $\begin{array}{l}\text { Severe atopic dermati- } \\
\text { tis (SCORAD 64-95) }\end{array}$ & $\begin{array}{l}\text { Severe atopic dermati- } \\
\text { tis (SCORAD 52-78) }\end{array}$ & Recurrent urticaria \\
\hline Family history & $\begin{array}{l}\text { Positive (mother has per- } \\
\text { sistent allergic rhinitis) }\end{array}$ & Negative & $\begin{array}{l}\text { Positive (mother has } \\
\text { atopic dermatitis) }\end{array}$ \\
\hline Total IgE (IU/ml) & 17357 & 4075 & 340 \\
\hline $\begin{array}{l}\text { Sensitization to } \\
\text { food allergens }\end{array}$ & $\begin{array}{l}\text { Milk, buckwheat, } \\
\text { egg, wheat, potato, } \\
\text { soy, nuts, fish }\end{array}$ & Milk, egg & Milk \\
\hline $\begin{array}{l}\text { Median wheal diameter } \\
\text { of skin prick test (milk) }\end{array}$ & $\begin{array}{c}\text { Not applicable } \\
\text { (anaphylaxis) }\end{array}$ & $6 \mathrm{~mm}$ & $8 \mathrm{~mm}$ \\
\hline $\begin{array}{l}\text { Cow's milk } \\
\text { protein-specific IgE } \\
\text { concentration, kUA/1 }\end{array}$ & $\begin{array}{c}\text { Casein - 32.84; } \\
\alpha \text {-Lactalbumin - 41.37; } \\
\beta \text {-Lactoglobulin }-41.12 ; \\
\text { Bos d_milk }-42.06\end{array}$ & $\begin{array}{c}\text { Casein }-2.42 ; \\
\text { Bos d_milk - } 17.9\end{array}$ & $\begin{array}{c}\text { Casein - 1.56; } \\
\text { Bos d_milk-0.42; } \\
\alpha \text {-Lactalbumin - 0.02; } \\
\beta \text {-Lactoglobulin }-0.04\end{array}$ \\
\hline $\begin{array}{l}\text { Maximum tolerated } \\
\text { dose of milk at first } \\
\text { double-blind placebo- } \\
\text { controlled challenge }\end{array}$ & $\begin{array}{l}\text { Not applicable } \\
\text { (anaphylaxis) }\end{array}$ & $3 \mathrm{ml}$ & $4.5 \mathrm{ml}$ \\
\hline
\end{tabular}

Prism 7.0 (GraphPad, San Diego, USA) software. A $P$ value of $\leq 0.05$ was considered statistically significant.

\section{Results}

With the objective of developing a multicolor histology approach for eosinophil evaluation we tested different combinations of stains. We aimed to primarily detect eosinophil granules, then to discriminate nuclear morphology (being an important morphological feature of eosinophils), and eventually to provide the ability to quantitatively estimate the number of surface markers. Our requirements were: a) use of available fluorescent labels to custom label antibodies of need, and b) absence of spectral overlap between detection channels to allow quantitative analysis. The tested combinations, as well as the result of their application, are summarized in Table 2.

The best combination was achieved when $A B$ was used for eosinophil granule staining (producing almost no overlap with other channels), FITC was used as an antibody label, and PI was used for DNA/ nucleus visualization (Fig. 1). This approach allowed clear discrimination of eosinophil granules and surface receptors. The obtained slides maintained in- tensity in all channels when preserved in an antifade mounting medium at $4{ }^{\circ} \mathrm{C}$ for at least 3 weeks. Besides, obtained data in our setup were compatible with deconvolution techniques, allowing clear visualization of eosinophils (Fig. 1, B).

Examples of discrimination of eosinophils from other blood cells, namely neutrophilic granulocytes can be seen in Fig. 1, $B$ and Fig. 2.

Combination of AB/antibody-FITC-/PI for blood smear staining also resulted in a metachromatic signal in the NIR region, which was only seen on eosinophilic granulocytes when AB and FITC were present, and thus can serve as an additional discrimination marker for specific devices (e.g., flow cytometer), which are usually equipped with far-red ability but not blue channels. Values of Pearson's correlation coefficient $(r)$ for co-localization were 0.85 for the FITC vs NIR channel, 0.82 for AB vs NIR and 0.34 for PI vs NIR, indicating the contributions of $\mathrm{AB}$ and FITC to the metachromatic signal (Fig. 3).

Having proposed an effective method of discrimination of eosinophils in blood smears and achieved simultaneous molecular labeling with the antigen of interest we used the current approach to study eosinophil changes during acute cow milk al- 
Table 2. Tested combinations of dyes for eosinophil identification and quantification of their surface receptors

\begin{tabular}{|l|c|c|c|}
\hline \multicolumn{1}{|c|}{$\begin{array}{c}\text { Eosinophilic } \\
\text { granules }\end{array}$} & DNA & Surface receptors & Result \\
\hline Eosin & DAPI & Anti-IgE - Cy5.5 & $\begin{array}{c}\text { Low specific signal, high background, } \\
\text { requires NIR optics }\end{array}$ \\
\hline Eosin & Sytox Green & Anti-IgE - AMCA & $\begin{array}{c}\text { Low specific signal, overlap of } \\
\text { red and green channels }\end{array}$ \\
\hline Methylene blue & PI & Anti-IgE - FITC & Low signal of granules \\
\hline Aniline blue & PI & Anti-IgE - FITC & $\begin{array}{c}\text { Good channel separation, + additional } \\
\text { discrimination in NIR }\end{array}$ \\
\hline
\end{tabular}

AMCA, 7-amino-4-methyl-3-coumarinylacetic acid; Cy5.5, a cyanine dye; DAPI, 4',6-diamidino-2-phenylindole; FITC, fluorescein isothiocyanate; NIR, near-infrared; PI, propidium iodide.

$A$

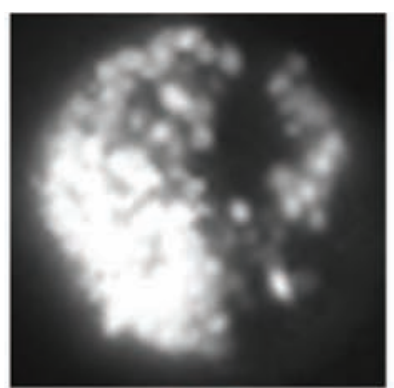

$A B$

ex. $350 / 60$, em. $440 / 25$

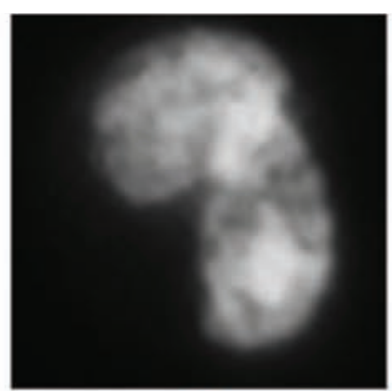

PI

ex. $550 / 20$, em. $610 / 40$
B

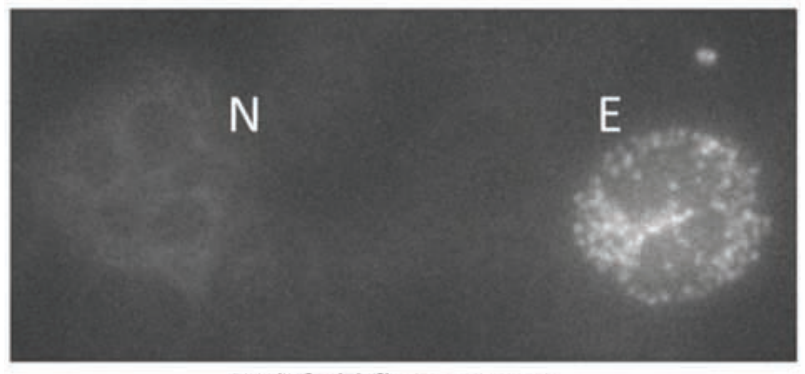

Widefield fluorescence

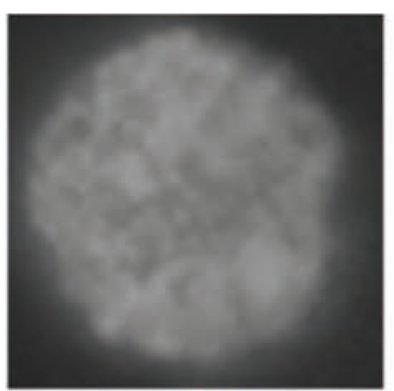

FITC

ex. $470 / 20$, em. $520 / 20$

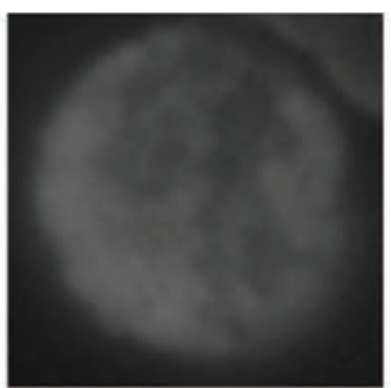

NIR-metachromatic ex. $630 / 20$, em. $700 / 60$

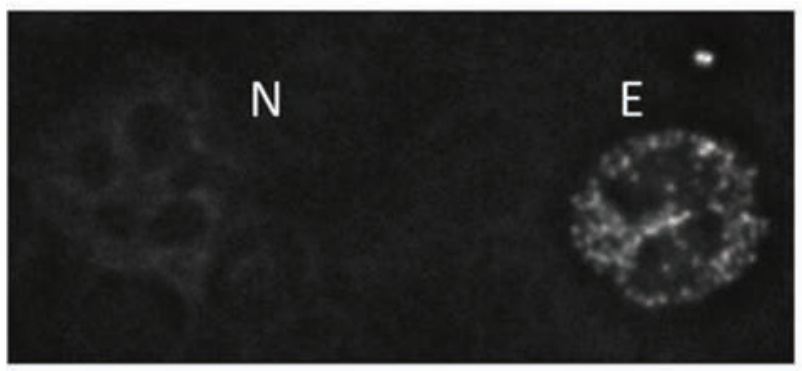

Widefield fluorescence + deconvolution

Fig. 1. Application of the developed multicolor fluorescent staining technique to detect eosinophils by staining their granules (aniline blue, AB), DNA (propidium iodide, PI) and surface receptors (antibodies labeled with fluorescein isothiocyanate, FITC). (A) imaging in each indicated separate fluorescent channel. (B) application of deconvolution techniques, discrimination of neutrophil (N) and eosinophil (E) in human blood smears. NIR, near-infrared

lergy in children. We were interested in the amounts of: a) IgE antibodies on eosinophils and b) caseinbinding targets since the casein protein serves as a primary allergen in cow milk allergy [13, 14]. As treatment with low doses of proteins serves as a common effective therapy for this disease, the data about IgE receptor changes during the disease course are not fully understood. Thus we labeled omali- zumab (anti-IgE antibodies) and casein protein with FITC and used them to study human blood smears. Blood smears from 3 children with acute cow milk allergy, all being responsive for the casein allergen, were screened for the amount of IgE molecules and casein binding targets on their eosinophils. Blood from 2 healthy children served as a control (NHD). During allergic conditions we observed greatly in- 

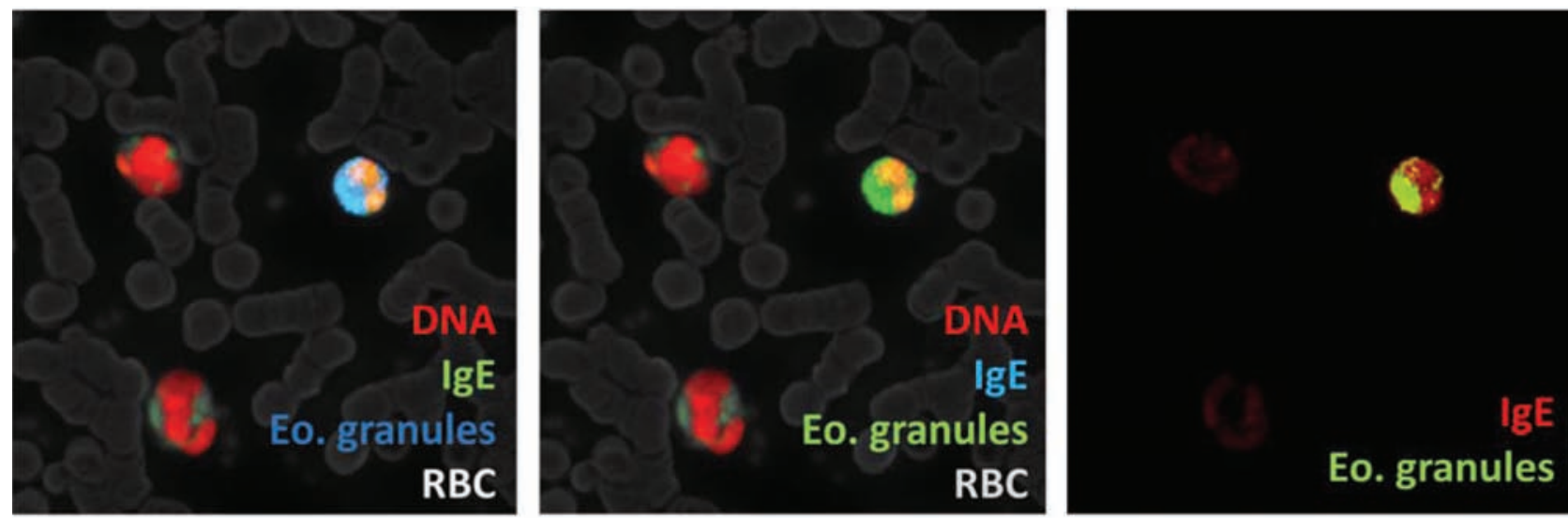

Fig. 2. Discrimination of eosinophils in whole blood smears using the proposed approach to stain DNA with propidium iodide (PI), eosinophilic (Eo.) granules with aniline blue (AB), and surface IgE with the corresponding anti-IgE antibody labeled with fluorescein isothiocyanate (FITC). Red blood cell (RBC) autofluorescence is observed mainly in the near-infrared (NIR) channel. The combinations of used channels are indicated in each image.

creased sizes of eosinophils. Thus for microscopic imaging of cellular smears we calculated integrated optical density (IOD, area of fluorescence integrated with fluorescent signal) and mean fluorescent intensity (MFI, mean fluorescent signal within each cell) for eosinophilic granulocytes detected by their ABmediated staining. The PI signal served to verify cell nuclear morphology. Fluorescent beads served as an internal size control [15]. Image quantification with NIH software revealed that amounts of both IgE receptors and casein binding targets were increased on the eosinophils of children suffering from cow milk allergy vs NHD (Fig. 4).

\section{Discussion}

The proposed method to discriminate blood eosinophils using blue fluorescence after staining eosinophil granules was effective in multicolor fluorescent histological assessment. It allowed one to observe nuclear morphology, usually bi-lobed in eosinophils, but never segmented, and use one common fluorescent bandwidth for analytical parameters to be studied such as surface/intercellular receptors. The proposed approach for eosinophil determination and quantification of their surface receptors was validated for case studies of patients with cow milk
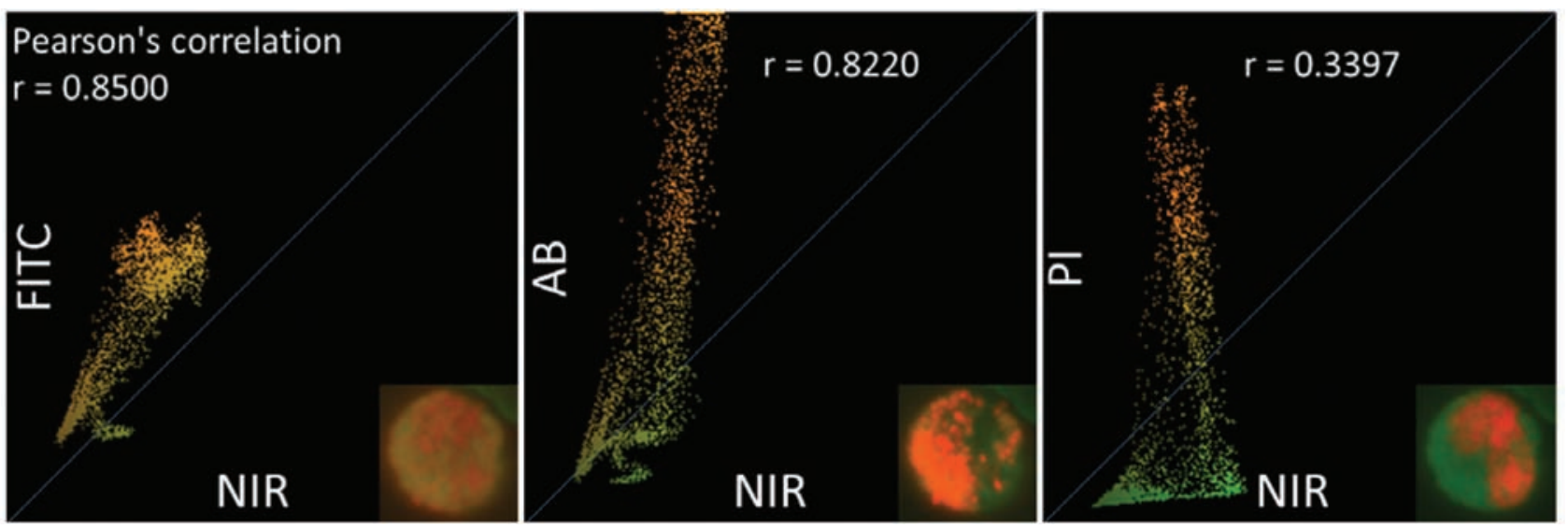

Fig. 3. Localization of metachromatic signal at the near-infrared (NIR) channel with signal of fluorescein isothiocyanate (FITC), aniline blue (AB) and propidium iodide (PI) in the combined staining system. Data indicate calculated values of Pearson's correlation coefficient (r) for co-localization. Inserts demonstrate typical cellular localization of analyzed signals 
$A$

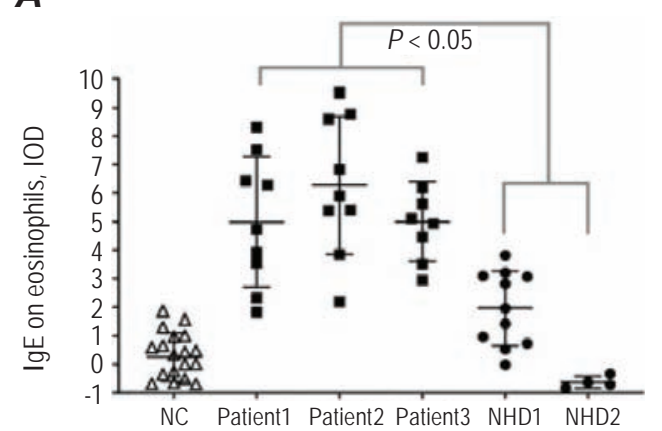

B

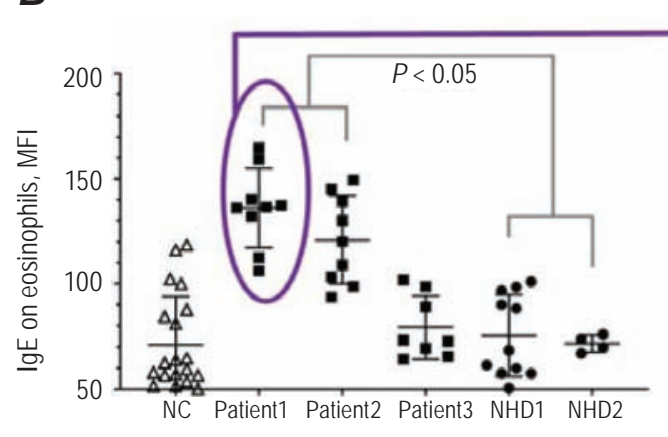

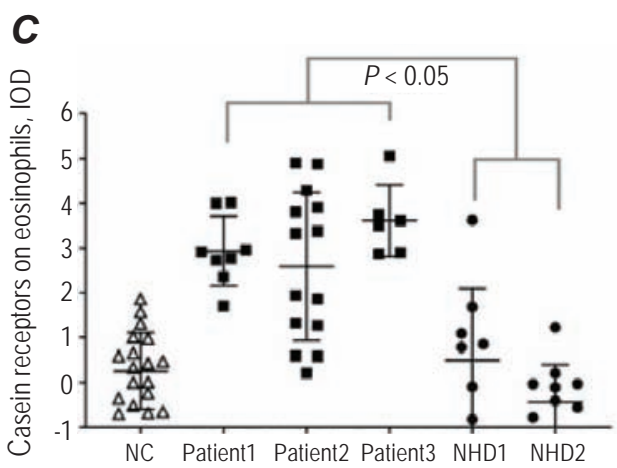

D

Patient 1, Acute allergy to cow milk

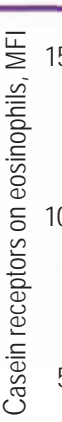

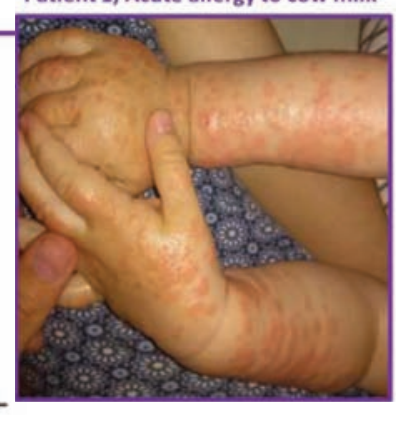

Fig. 4. Application of the proposed method for eosinophil discrimination to evaluate the amounts of (A, B) eosinophil-related IgE molecules and $(\boldsymbol{C}, \boldsymbol{D})$ casein-binding targets on eosinophils. The quantifications of integrated optical density (IOD) and mean fuorescent intensity (MFI) were done for blood smears of 3 children suffering from cow milk allergy and 2 healthy controls (NHD, normal healthy donors). NC, negative control (cells of Patient 1 with eosinophil specific granules but no FITC staining). Insert photo shows Patient 1 during the period of blood analysis

allergy and demonstrated a statistically significant increase of IgE receptors as well as casein-binding targets on the surface of eosinophils from cow milk allergy patients compared to eosinophils from healthy children. These provides a new methodology for investigating eosinophil changes during associated pathologies.

Conflict of interest. Authors have completed the Unified Conflicts of Interest form at http://ukrbiochemjournal.org/wp-content/uploads/2018/12/ coi_disclosure.pdf and declare no conflict of interest.

Ethical Committee Approval. Ethics committee of Danylo Halytsky Lviv National Medical Univer- sity, protocol 20170223/5 and NCE “City Children's Clinical Hospital of Lviv”; 20181116/6.

Acknowledgements and financial support. This work was partly supported by the Grant from the Ministry of Healthcare of Ukraine 0119U101335 and Volkswagen Stiftung Project 97744, Polish National Science Center (FUGA Project no. 2016/20/S/ ST3/00277) and RECOOP Young Scientist Research Grant 009. We are thankful to Cedars-Sinai Medical Center's International Research and Innovation in Medicine Program, and the Association for Regional Cooperation in the Fields of Health, Science and Technology (RECOOP HST Association) for their support. 


\section{НОВИЙ СПОСІБ ДИСКРИМІНАЦІЇ ЕОЗИНОФІЛЬНИХ ГРАНУЛОЦИТІВ ТА ОЦІНКИ ЇХНІХ ПОВЕРХНЕВИХ РЕЦЕПТОРІВ ІЗ ВИКОРИСТАННЯМ БАГАТОКОЛІРНОГО ГІСТОЛОГІЧНОГО АНАЛІЗУ}

\author{
Г. Біла ${ }^{1}$, М. Шнайдер ${ }^{1}$, С. Пешкова 1 , \\ Б. Крайнік2, Л. Беш' \\ О. Маиюра ${ }^{3 凶}$, Р. Білий
}

\footnotetext{
${ }^{1}$ Кафедра гістології, цитології та ембріології, Львівський національний медичний університет імені Данила Галицького, Україна; ${ }^{2}$ Факультет фундаментальних проблем технології, Вроцлавський університет науки та технології, Вроцлав, Польща; ${ }^{3}$ Кафедра педіатрії 2, Львівський національний медичний університет імені Данила Галицького, Україна;

凶e-mail: r.bilyy@gmail.com; omatsyura@gmail.com
}

Еозинофільні гранулоцити забезпечують імунну відповідь проти багатоклітинних паразитів, а також є головним фактором таких патологічних станів, як алергія та астма. Еозинофіли дискримінуються за допомогою фарбування еозином за використання світлової мікроскопії. Однак для молекулярного виявлення антигенів та широко впроваджених автоматизованих аналізаторів зазвичай потрібні флуоресцентні маркери придатні для кількісного аналізу. Проте, не існує селективного CD маркера для диференціації еозинофілів і базофілів, а нещодавно описані аналоги для заміщення гематоксилін-еозину для флуоресцентної детекції з використанням DRAQ5-еозину, також виявлись непридатними для детекції еозинофілів. Різні комбінації флуоресцентних барвників випробовували за допомогою флуоресцентної мікроскопії, спрямованої на розробку простого та специфічного методу виявлення еозинофільних гранул, ДНК та поверхневих рецепторів; підхід був використаний для оцінки рівнів $\operatorname{IgE}$ (загального та специфічного до казеїну) на клітинах пацієнтів із алергією на коров'яче молоко. Нам вдалося досягти селективної візуалізації гранул еозинофілів за допомогою барвника анілінового синього, модифікувавши метод Berretty \& Cormane (1978) та виявляючи сигнал при 440 нм; це дозволило одночасно фарбувати мазки крові антитілами до IgE-FITC (емісія при 520 нм) та казеїнFITC, виявляти ДНК пропідію йодидом (емісія 590 нм), а також забезпечувало специфічний метахроматичний сигнал еозинофілів у ближній інфрачервоній області спектру (емісія 700 нм) 3 подальшою кількісною оцінкою флуоресцентного сигналу. Застосування запропонованого підходу до клінічних випадків виявило підвищення рівня IgE та мішеней зв'язування казеїну на еозинофілах у 3 пацієнтів із алергією на коров'яче молоко порівняно з 2 здоровими донорами, що демонструє загальну корисність запропонованого підходу.

К л ю ч о в і с л о в а: еозинофільні гранулоцити, алергія, $\operatorname{IgE}$, гістологія, детекція, клінічні випадки, молоко.

\section{References}

1. Ramirez GA, Yacoub MR, Ripa M, Mannina D, Cariddi A, Saporiti N, Ciceri F, Castagna A, Colombo G, Dagna L. Eosinophils from physiology to disease: A comprehensive review. Biomed Res Int. 2018; 2018: 1-28.

2. Boeltz S, Amini P, Anders HJ, Andrade F, Bilyy R, Chatfield S, Cichon I, Clancy DM, Desai J, Dumych T, Dwivedi N, Gordon RA, Hahn J, Hidalgo A, Hoffmann MH, Kaplan MJ, Knight JS, Kolaczkowska E, Kubes P, Leppkes M, Manfredi AA, Martin SJ, Maueröder C, Maugeri N, Mitroulis I, Munoz LE, Nakazawa D, Neeli I, Nizet V, Pieterse E, Radic MZ, Reinwald C, Ritis K, RovereQuerini P, Santocki M, Schauer C, Schett G, Shlomchik MJ, Hans-Uwe Simon, Skendros P, Stojkov D, Vandenabeele P, Berghe TV, van der Vlag J, Vitkov L, von Köckritz-Blickwede M, Yousefi S, Zarbock A, Herrmann M. To NET or Not to NET:current Opinions and State of the Science Regarding the Formation of Neutrophil Extracellular Traps. Cell Death Differ. 2019; 26(3): 395-408.

3. Mukherjee M, Lacy P, Ueki S. Eosinophil extracellular traps and inflammatory pathologies-untangling the web! Front Immunol. 2018; 9: 2763.

4. Paryzhak SY, Dumych TI, Bila GI, Bilyy RO. Application of air Pouch Model for Evaluation the Ability of Immune Cells to Sequester Foreign Nano- and Microparticles. Exp Clin Physiol Biochem. 2019; 85(1): 52-57. 
5. Bila G, Peshkova S, Dumych T, Bilyy R. Natural cholesterol nanocrystals in gall material and their interaction with neutrophilic granulocytes. In: PhoBiA Annual Nanophotonics International Conference. Wroclaw, 2019. p. 62.

6. Thermo Fisher. Immune cell guide: Antigens, human and mouse. 2017. $84 \mathrm{p}$.

7. Elfer KN, Sholl AB, Wang M, Tulman DB, Mandava SH, Lee BR, Brown JQ. DRAQ5 and Eosin ('D\&E') as an Analog to Hematoxylin and Eosin for Rapid Fluorescence Histology of Fresh Tissues. PLoS One. 2016; 11(10): e0165530.

8. Wollenberg A, Barbarot S, Bieber T, ChristenZaech S, Deleuran M, Fink-Wagner A, Gieler U, Girolomoni G, Lau S, Muraro A, CzarneckaOperacz M, Schäfer T, Schmid-Grendelmeier P, Simon D, Szalai Z, Szepietowski JC, Taieb A, Torrelo A, Werfel T, Ring J. Consensus-based European Guidelines for Treatment of Atopic Eczema (Atopic Dermatitis) in Adults and Children: Part I. J Eur Acad Dermatol Venereol. 2018; 32(5): 657-682.

9. Berretty PJ, Cormane RH. The aniline blue fluorescence staining of eosinophilic granulocytes. Br J Dermatol. 1978; 99(4): 377382.
10. Hermanson GT. Bioconjugate Techniques [Internet]. 3rd ed. London: Academic Press; 2013. $1200 \mathrm{p}$.

11. Bilyy R, Tomyn A, Kit Y, Podhorodecki A, Misiewicz J, Nyk M, Strek W, Stoika R. Detection of dying cells using lectin-conjugated fluorescent and luminescent nanoparticles. Materwiss Werksttech. 2009; 40(4): 234-237.

12. Sojka B, Podhorodecki A, Banski M, Misiewicz J, Drobczynski S, Dumych T, Lutsyk MM, Lutsyk A, Bilyy R. $\beta-\mathrm{NaGdF}_{4}: \mathrm{Eu}^{3+}$ nanocrystal markers for melanoma tumor imaging. RSC $A d v$. 2016; 6(63): 57854-57862.

13. Wal JM. Cow's milk allergens. Allergy. 1998; 53(11): 1013-1022.

14. Wal JM. Cow's milk proteins/allergens. Ann Allergy Asthma Immunol. 2002; 89(6 Suppl 1): 3-10.

15. Grama S, Boiko N, Bilyy R, Klyuchivska O, Antonyuk V, Stoika R, Horak D. Novel fluorescent poly(glycidyl methacrylate) - Silica microspheres. Eur Polym J. 2014; 56: 92-104. 